\title{
POLA BAKTERI PENYEBAB PNEUMONIA NOSOKOMIAL DI RS DR SOETOMO SURABAYA PERIODE JANUARI 2011 - MARET 2012
}

\author{
Asadullah $^{1}$, Isbandiyah ${ }^{2}$, Sri Ardila $\mathbf{N}^{3}$ \\ Fakultas Kedokteran Universitas Muhammadiyah Malang, J1. Bendungan Sutami No. 188A, Malang, 65145, \\ Indonesia, 0341-551149
}

\begin{abstract}
ABSTRAK
Asadullah, 2012. Pola Bakteri Penyebab Pneumonia Nosokomial di RS Dr.Soetomo Surabaya Periode Januari 2011 - Maret 2012, Latar Belakang: Pneumonia nosokomial merupakan penyebab mortalitas dan morbiditas yang paling tinggi diantara infeksi nosokomial lainnya. Tujuan penelitian: Mengetahui pola bakteri penyebab pneumonia nosokomial di RS Dr.Soetomo Surabaya periode Januari 2011 - Maret 2012 Metode Penelitian: Rancangan deskriptif dengan pendekatan cross sectional. Data dari rekam medik, diolah secara deskriptif untuk mengetahui pola bakteri penyebab pneumonia nosokomial di RS Dr.Soetomo Surabaya. Hasil dan diskusi Jumlah pederita pneumonia nosokomial di RS Dr.Soetomo surabaya periode januari 2011-maret 2012 adalah 812 orang.
\end{abstract}

\section{ABSTRACT}

Asadullah, 2012. Bacterial Pattern Caused Nosocomial Pneumonia At RS Dr.Soetomo Surabaya Period January 2011 - March 2012, Background: Nosocomial pneumonia is a major cause of mortality and morbidity among other nosocomial infections. Objective: To know about bacterial pattern caused nosocomial pneumonia at RS Dr. Soetomo Surabaya period January 2011 - March 2012. Method: Descriptive device by cross sectional. Data from medical report, analyze by descriptive method to know about bacterial pattern occurrence of nosocomial pneumonia at RS Dr.Soetomo Surabaya. Result and Conclution: amount of nosocomial pneumonia medical patients at RS Dr. Soetomo Surabaya period January 2011-March 2012 are 812 patients.

Key words: Bacterial Pattern, Nosocomial pneumonia

\section{PENDAHULUAN}

Infeksi nosocomial (acquiredhospital infection/nosocomial infection) adalah infeksi yang didapat ketika penderita itu dirawat di rumah sakit. Infeksi nosokomial merupakan salah satu penyebab kematian serta meningkatnya lama perawatan di rumah sakit (WHO, 2002). Biaya untuk infeksi nosokomial ddiperkirakan mencapai 5-10 juta dollar setiap tahunnya (Peleg, Hooper, 2010).

Diantara penyebab infeksi nosokomial, pneumonia nosokomial menempati urutan ke-2 setelah infeksi saluran kemih, yaitu 5-50 kasus per 1.000 perawatan di RS setiap tahun. Insiden ini dilaporkan meningkat 5-10 kali jika pasien dirawat di ICU dan menjadi 6-20 kali jika pasien menggunakan ventilator (Leeper, 2003). Pneumonia memang menempati urutan ke-2 diantara penyebab infeksi nosokomial, tapi merupakan penyebab mortalitas dan morbiditas yang paling tinggi diantara infeksi nosokomial lainnya (ATS, 2005). Angka mortalitas pneumonia nosokomial diketahui mencapai $33-50 \%$, yang dapat meningkat sampai $70 \%$ bila termasuk yang meninggal akibat penyakit dasar yang didieritanya (Dahlan, 2009). Menurut penelitian oleh Roger C Bone di rumah sakit Bichat Paris, dari 1978 pasien yang telah dirawat di ICU setelah 48 jam ditemukan 328 (16,6\%) pasien dengan komplikasi pneumonia nosokomial yang dimana angka mortalitas dari kelompok ini adalah 52,4\% sedangkan pada kelompok pasien tanpa komplikasi pneumonia nosokomial, hanya didapatkan angka mortalitas sebesar 22,4\% (Bone, Huchard, 2006)
Mikroorganisme terseringpenyebab pneumonia nosokomial adalah bakteri, yang jenisnya berbeda antar negara, antara satu daerah dengan daerah lain pada satu negara, diluar RS dan di dalam RS, antara RS besar / tersier dengan RS yang lebih kecil. Selain itu pneumonia dapat juga disebabkan oleh jamur, protozoa dan virus walaupun ini merupakan keadaan yang tidak lazim (Zubir, 2006) dan sangat jarang pada pasien yang tidak disertai kelainan imun (ATS, 2005).

\section{METODE}

Penelitian ini dilakukan dengan menggunakan rancangan deskriptif dengan pendekatan cross sectional. Penelitian ini dilaksanakan di bagian rekam medik RS Dr.Soetomo Surabaya pada bulan maret 2012. Populasi pada penelitian ini adalah seluruh pasien dengan diagnosa pneumonia nosokomial di Puskesmas RS Dr.Soetomo Surabaya (periode 1 Januari 2011 - 30 Maret 2012). Populasi pada penelitian ini adalah seluruh pasien dengan diagnosa pneumonia nosokomial di Puskesmas RS Dr.Soetomo Surabaya (periode 1 Januari 2011 - 30 Maret 2012). Pada penelitian ini pengambilan sampel dilakukan secara total Sampling dalam kurun waktu 1 tahun Januari 2011 Maret 2012). 


\section{HASIL DAN PEMBAHASAN}

Berdasarkan hasil penelitian dari data rekam medis pada penderita pneumonia nosokomial yang dirawat di RS Dr.Soetomo, pada periode Januari 2011 sampai dengan Maret 2012 didapatkan 812 penderita. 25 data penderita diantaranya memenuhi kriteria inklusi yaitu pasien pneumonia nosokomial yang mempunyai keterangan tentang hasil kultur dalam data rekam medis. Penentuan besar sampel dengan menggunakan tehnik total sampling sebesar 25.

Penderita pneumonia nosokomial di RS Dr.Soetomo pada periode Januari 2011 samapai Maret 2012 diketahui sebanyak 812 penderita dan 25 diantaranya memiliki keterangan tentang bakteri penyebab pneumonia nosokomial tersebut yang didapatkan melalui hasil kultur. Dari 25 pasien dengan keterangan hasil kultur diketahui 4 pasien menderita pneumonia nosokomial disebabkan oleh acinetobacter spp, 1 pasien oleh klebsiella pneumoniae dan acinetobacter baumannii, 1 pasien oleh proteus mirabilis, 6 pasien oleh pseudomonas aeruginosa, 1 pasien oleh citrobacter freundii, acinetobacter spp dan pseudomonas aeruginosa, 2 pasien oleh klebsiella pneumoniae, 1 pasien oleh klebsiella oxytoca, pseudomonas aeruginosa, bokholderia cepacia, acinetobacter baumannii, 1 pasien oleh pantoea agglomerans, 2 pasien oleh staphylococcus aureus, 1 pasien oleh acinetobacter spp, pseudomonas aeruginosa, 2 pasien oleh enterobacter aeruginosa, dan 3 pasien oleh acinetobacter baumannii.

Berdasarkan data yang diperoleh dari 25 sampel diketahui 4 pasien berada pada usia 10-19 tahun, 4 pasien berada pada usia 20-29 tahun, 6 pasien berada pada usia 3039 tahun, 4 pasien berada pada usia 40-49 tahun, sedangkan 7 lainnya berada pada usia $>50$ tahun.

Berdasarkan hasil penelitian dari 25 sampel dapat dikelompokkan menjadi beberapa golongan berdasarkan waktu terjadinya pneumonia nosokomial. Sebanyak 6 pasien menderita pneumonia nosokomial setelah 3-5 hari perawatan, 6 pasien setelah 6-8 hari perawatan, 5 pasien setelah 9- 11 hari perawatan, 4 pasien setelah $12-15$ hari perawatan, 4 pasien setelah $>16$ hari perawatan. Berikut ini tabel tentang lama perawatan dan jumlah sampel.

Berdasarkan data yang diperoleh dari 25 sampel diketahui bahwa 17 diantaranya menderita cedera otak berat (COB), 6 lainnya menderita cedera otak sedang (COS), sedang 2 sisanya menderita cedera otak ringan (COR).

Berdasarkan data yang diperoleh dari 25 sampel diketahui 7 diantaranya dirawat di ruang observasi intensif (ROI) dan 18 lainnya di rawat di ruang bedah flamboyan (BF). Diantara 7 pasien yang mendapat perawatan di ROI 3 pasien disebabkan oleh pseudomonas aeruginosa, 3 pasien oleh acinetoacter spp, dan 1 pasien disebabkan oleh pantoea agglomerans. Sedangkan dari 18 pasien yang mendapat perawatan di ruang BF 3 pasien disebabkan oleh pseudomonas aeruginosa, 1 pasien oleh klebsiella pneumoniae dan acinetobacter baumannii, 1 pasien oleh proteus mirabilis, 1 pasien oleh citrobacter freundii, acinetobacter spp dan pseudomonas aeruginosa, 2 pasien oleh klebsiella pneumoniae, 1 pasien oleh klebsiella oxytoca, pseudomonas aeruginosa, bokholderia cepacia, acinetobacter baumannii, 1 pasien oleh acinetobacter spp, 2 pasien oleh staphylococcus aureus, 1 pasien oleh acinetobacter spp dan pseudomonas aureus, 2 pasien oleh enterobacter aeruginosa, dan 3 pasien oleh acinetobacter baumannii.

Berdasarkan data yang diperoleh dari 25 sampel diketahui 8 diantaranya meninggal dunia dan 17 sisanya hidup. Dari 8 pasien yang meninggal dunia semuanya memiliki diagnosa COB (cedera otak berat) sebagai diagnosa utamanya dan pneumonia nosokomial sebagai diagnosa sekundernya.

Berdasarkan hasil penelitian diketahui bahwa di RS Dr.Soetomo periode Januari 2011-Maret 2012, terjadi sebanyak 812 kejadian pneumonia nosokomial dan 25 pasien diantaranya diketahui hasil kultur bakteri patogen penyebabnya.

Dari 25 pasien yang memiliki hasil kultur bakteri, diketahui bahwa bakteri tersering penyebab pneumonia nosokomial adalah pseudomonas aeruginosa sebanyak $24 \%$ di ikuti acinetobacter spp sebanyak 16\%, acinetobacter baumanii sebanyak $12 \%$, klebsiella pneumoniae, enterobacter aeruginosa dan staphylococcus aureus masing- masing $8 \%$, proteus mirabilis $4 \%, \quad$ klebsiella pneumoniae dan acinetobacter baumannii 4\%, klebsiella oxytoca, pseudomonas aeruginosa, bokholderia cepacia dan acinetobacter baumannii 4\%, citrobacter freundii, acinetobacter spp dan pseudomonas aeruginosa $4 \%$, pantoea agglomerans $4 \%$, acinetobacter spp dan pseudomonas aeruginosa 4\%. Data ini menunjukkan perbedaan dibandingkan dengan data sebelumnya di RS Dr.Soetomo pada tahun 2002 dimana diketahui pseudomonas aeruginosa sebagai bakteri yang paling dominan sebagai penyebab pneumonia nosokomial dengan angka kekerapan sebesar 48,78\%, di ikuti klebsiella pneumoniae sebesar 19,51\%, pseudomonas ssp 12,2\%, eschercia coli $7,32 \%$, enterobacter $4,89 \%$, staphylococcus $4,89 \%$, dan candida $2,44 \%$.

Hal ini sesuai dengan literature, salah satunya menurut Joseph P Lynch yang mengatakan bahwa pola bakteri penyebab pneumonia nosokomial dapat berubah- ubah setiap waktu. Hal serupa juga dikemukakan oleh Zul Dahlan dimana menurut penelitiannya di Rumah Sakit Hasan Sadikin yang menyimpulkan bahwa telah terjadi perubahan pola bakteri penyebab pneumonia nosokomial pada pasien yang mengidap penyakit kronis dibandingkan dengan tahuntahun sebelumnya.

Usia tertinggi pada pasien pneumonia nosokomial adalah pada usia $>50$ tahun yaitu sebesar $28 \%$, sedangkan pada usia 30-39 tahun $24 \%$, usia $10-19$ tahun $16 \%$, usia 20 29 tahun 16\%, usia 40-49 tahun 16\%. Hal ini sesuai dengan penelitian yang dilakukan Burke A Cunha yang mengatakan bahwa usia merupakan salah satu faktor resiko pneumonia nosokomial dimana pasien-pasien yang berusia tua lebih sering terkena pneumonia nosokomial dikarenakan faktor daya tahan tubuh yang mulai berkurang.

Mengenai karakteristik sampel terhadap waktu terjadinya pneumonia nosokomial dapat dilihat pada tabel 4.3 bahwa $24 \%$ sampel menderita pneumonia nosokomial setelah 3-5 hari perawatan, 24\% setelah 6-8 hari perawatan, 20\% setelah 9-11 hari perawatan, $16 \%$ setelah $12-15$ hari perawatan dan $16 \%$ sisanya setelah $>16$ hari perawatan. Dari data tersebut dapat di amati bahwa kejadian pneumonia nosokomial lebih sering pada saat-saat awal pasien dirawat di rumah 
sakit. Data ini berbeda dengan literature yang mengatakan bahwa faktor resiko pneumonia nosokomial meningkat seiring lamanya perawatan di rumah sakit.

Kemungkinan hal ini disebabkan oleh perbedaan jenis pneumonia nosokomial yang terjadi. Seperti dijelaskan sebelumnya pada bab 2 bahwa pneumonia nosokomial dapat di picu oleh banyak hal seperti masuknya bakteri melalui inhalasi, aspirasi cairan lambung, dan salah satunya oleh pemasangan ventilator. Dengan melihat bahwa sebagian besar sampel yaitu $68 \%$ pasien menderita cedera otak berat sebagai diagnosis primer, kemungkinan besar pneumonia nosokomial yang terjadi pada pasien-pasien ini diakibatkan oleh pemasangan ventilator mengingat standar perawatan pada pasien dengan cidera otak berat menurut Satyanegara memerlukan pemasangan ventilator segera setelah pasien masuk ICU. Disebutkan pada literature lainnya yang di terbitkan oleh American Thoracic Society (ATS) bahwa resiko pneumonia nosokomial pada pasien-pasien pneumonia akibat ventilator tertinggi adalah pada saat awal pasien masuk ICU. Dikarenakan pada data yang kita dapatkan melalui rekam medik tidak dicantumkan mengenai jenis pneumonia nosokomial apa yang terjadi dan intervensi yang dilakukan terhadap pasien seperti pemasangan ventilator, maka sulit untuk menganalisa tentang karakteristik antara sampel terhadap lama perawatan.

Diketahui 68\% pasien menderita cedera otak berat (COB), 24\% menderita cedera otak sedang (COS), dan 8\% sisanya menderita cedera otak ringan (COR). Sebagaimana dikemukakan oleh Burke A Cunha faktor resiko dari pneumonia nosokomial dapat dibagi menjadi 2 yaitu yang berhubungan dengan daya tahan tubuh dan faktor eksogen. Menurut literature diketahui bahwa cedera otak dapat mempengaruhi daya tahan tubuh melalui beberapa jalan yaitu gangguan pada refleks batuk yang menyebabkan mudahnya terjadi aspirasi dari oropharing serta gangguan pertahanan tubuh humoral berupa gangguan pada gerakan silia yang ada pada saluran nafas, pemberian obat-obatan kortikosteroid untuk mengatasi edema cerebri juga berperan dalam menurunkan pertahanan tubuh pasien. Selain itu pada beberapa pasien dengan cedera otak memerlukan pemasangan ventilasi mekanik dan tindakan tracheostomy untuk menunjang pernafasan, pemasangan ventilasi mekanik dan tracheostomy yang tidak dilakukan secara aseptis dapat menjadi jalan masuk bakteri ke saluran nafas bawah yang langsung melewati pertahanan humoral tubuh berupa silia di saluran nafas yang akhirnya dapat memicu pertumbuhan bakteri di parenkim paru dan menyebabkan terjadinya pneumonia nosokomial. Menurut Kim M Kerr melalui hasil penelitiannya tentang faktor resiko tertentu pada bakteri penyebab pneumonia nosokomial, pola bakteri yang ditemukan pada sampel sesuai dengan faktor resiko pada cedera otak berat dimana dikatakan oleh Kim M Kerr bahwa bakteri yang identik pada pasien cedera otak berat adalah staphylococcus aureus sedangkan bakteri yang identik dengan perawatan di ICU dan pemasangan ventilator adalah pseudomonas aeruginosa.

Jumlah populasi pneumonia nosokomial dari seluruh kamar perawatan diketahui sebanyak 812 pasien, sedangkan yang masuk kedalam kriteria sampel yaitu pasien pneumonia nosokomial dengan keterangan hasil kultur hanya 25 pasien. Dari data tersebut dapat disimpulkan bahwa banyak sekali pasien pneumonia yang tidak memiliki keterangan hasil kultur bakteri pada rekam medis-nya. Menurut PDPI hal ini dapat disebabkan karena penulisan rekam medis yang kurang baik atau tidak dilakukannya kultur bakteri pada pasien-pasien pneumonia nosokomial. Hal ini menjelaskan pernyataan Zul Dahlan dan PDPI bahwa Indonesia belum memiliki data mengenai pola kuman penyebab pneumonia nosokomial yang umum. Oleh karena itu meskipun pola kuman di luar negri tidak sepenuhnya cocok dengan pola kuman di Indonesia, maka pedoman yang berdasarkan pola kuman di luar negri dapat di pakai sebagai acuan umum penatalaksanaan terapi empirik.

Berdasarkan hasil penelitian tersebut dapat dilihat adanya perbedaan pola bakteri penyebab pneumonia nosokomial diantara ruang observasi intensif dengan ruang bedah flamboyan. Hal ini sesuai dengan apa yang dikemukakan oleh Zul Dahlan bahwa terdapat perbedaan pola bakteri penyebab pneumonia nosokomial pada tiap daerah rumah sakit bahkan ruang perawatan pada rumah sakit yang sama.

Pada beberapa sampel dapat ditemukan lebih dari satu hasil kultur bakteri penyebab pneumonia nosokomial, akan tetapi merujuk pada hasil kultur bakteri terakhir yang didapatkan sebelum pasien meninggal sebanyak 4 atau setengah dari jumlah pasien yang meninggal memiliki hasil kultur pseudomonas aeruginosa diikuti acinetobacter baumannii 2 orang, sisanya staphylococcus aureus dan acinetobacter spp. Dari hasil ini dapat di lihat bahwa pseudomonas aeruginosa memiliki virulensi yang lebih tinggi dibanding bakteri lainnya.

Pada beberapa literature lainnya disebutkan bahwa selain pseudomonas aeruginosa ada beberapa bakteri lain yang berpotensi untuk menimbulkan resistensi terhadap antibiotik yang mana ini akan menyebabkan sulitnya terapi, menetapnya pneumonia yang berkepanjangan dan berujung pada peningkatan mortalitas atau

angka kematian. Bakteri-bakteri ini adalah acinetobacter baumannii, dan staphylococcus aureus. Acinetobacter baumannii meupakan bakteri gram negatif yang memiliki karakteristik mudah resisten terhadap kebanyakan antibiotik seperti aminoglycoside, fluoroquinolone, dan carbapenem. Meskipun virulensinya tidak setinggi pseudomonas aeruginosa tetapi terjadinya resistensi terhadap beberapa antibiotik akan dapat mempersulit terapi. Staphylococcus aureus adalah bakteri gram positif berbentuk kokus yang tergolong bakteri yang berpotensi menyebabkan resistensi. Virulensi Staphylococcus aureus meningkat seiring dengan terjadinya resistensi terhadap antibiotik, meskipun di Indonesia kejadian pneumonia nosokomial akibat staphylococcus aureus jarang di temukan tetapi di beberapa negara seperti Australia dan Amerika telah banyak ditemukan staphylococcus aureus yang berevolusi menjadi MRSA (methicillin resistant staphylococcus aureus) yang sering menimbulkan keadaan urgensi..

\section{SIMPULAN}

Berdasarkan hasil penelitian yang telah dilakukan, maka dapat ditarik kesimpulan sebagai berikut: Jumlah penderita pneumonia nosokomial di Rumah Sakit Dr.Soetomo 
periode 1 januari 2011 - 30 Maret 2012 adalah 812 orang. Bakteri patogen terbanyak penyebab pneumonia nosokomial di Rumah Sakit Dr.Soetomo adalah pseudomonas aeruginosa. Kejadian pneumonia nosokomial terbanyak pada usia $>50$ thn. Kejadian pneumonia nosokomial paling sering terjadi pada awal pasien dirawat di RS yaitu setelah 3-4 dan 5-8 hari perawatan. Pneumonia nosokomial lebih sering terjadi pada pasien-pasien dengan diagnosa primer COB (cedera otak berat). Pasien-pasien pneumonia nosokomial akibat pseudomonas aeruginosa memiliki prognosis paling buruk diantara pasien-pasien dengan bakteri lain.

\section{DAFTAR PUSTAKA}

American Thoracic Society Documents. Guidelines for the Management of Adults with Hospital-acquired, Ventilator-associated, and Healthcare-associated Pneumonia. Am J Respir Crit Care Med. 2005;171:388416

Bone C Roger, Huchard Henri. The role that nosocomial pneumonia plays in the outcome of intensive care unit patients. JAMA 2006;275:866-869

Cavanilas A Bueno, Rodriguez M Delgado, Luque A Lopez, Cano S Schaffino, Vargas R Galvez 2004. Influence of nosocomial infection on Mortality rate in an intensive care unit. Department of Preventive Medicine, University of Granada Hospital, Spain. Critical Care Medicine 2004: 55- 60

Celis R, Torres A, Gatell J M, Almela M, Rodriguez-Roisin $\mathrm{R}$ and Agusti-Vidal A. Nosocomial Pneumonia: A multivariate analysis of risk and prognosis. Chest 2006; 93;318-324

Corwin Elizabeth J, 2009, Buku Saku Patofisiologi, Penerbit Buku Kedokteran EGC, Jakarta

Cunha A Burke 2001. Nosocomial Pneumonia : Diagnostic and therapeutic considerations. The Medical Clinics of North America 2001: 79 - 114

Cunha A Burke, 2011. Nosocomial Pneumonia. http:// emedicinemedscape.com/ article/234753-overview

Dahlan Zul, 2009. Buku ajar ilmu penyakit dalam, interna publishing, Jakarta.

Dahlan Zul, 2005. Cermin Dunia Kedokteran No. 121

Daud A Shiraz, Kollef H Marin. Hospital-acquired pneumonia. The Washington Manual Pulmonary Medicine Subspecialty Consult. Lippincot Williams \& Wilkins. USA, 2006;13:84-7

Drakulovic B Mitra, Torres Antoni, Bauer T Torsten, Nicolas M Jose, Ferrer Miquel. Supine body position as a risk factor for nosocomial pneumonia in mechanically ventilated patients: a randomised trial. The Lancet 2009;354:1851-1858

Ewig S, Bauer Torsten T, Torres Antoni. The pulmonary physician in critical care-4: Nosokomial pneumonia. Thorax 2002;57;366-371

Fiel Stanley, Jones Ronald. Guidelines and critical pathways for severe hospital- acquired pneumonia. Chest, 2001;119:412-418

Kenneth V.Leeper, Marc Moss. Infectious Lung Disease Bacterial Pneumonia. Current Diagnosis \& Treatment in Pulmonary Medicine. McGraw-Hill Int. USA. 2003; 36:361-9
Kerr M Kim. Hospital-Acquired Pneumonia. Manual of Clinical Problem in Pulmonary Medicine. Edisi ke-6. Lippincott William \& Wilkins. USA. 2006; 13:84-7

Koening M. Steven and Jonathon D. Truwit, 2006. Ventilator-associated pneumonia: Diagnosis, Treatment, and Prevention, Pulmonary and critical care medicine, university of virginia, charlottesville, virginia 22908

Leuenberger Phillipe, Koerfer Jacques, Blum Andre, Perret Claude, Spinnler Oliver, Francioli Patrick. Nosocomial pneumonia in mechanically ventilated patients receiving antacid, ranitidine, or sucralfate as prophylaxis for stress ulcer. Ann Intern Med, 2004;120:653-662

Lynch P Joseph. Hospital-acquired pneumonia*risk factor, microbiology, and treatment. Chest, 2001;119:373S$384 \mathrm{~S}$

Martin S Gregory, 2005. Hospital-acquired pneumonia. http://www.medscape.com/ view article/506080_2

Mastertoni G, A. Galloway, G. French. Guidelines for the management of hospital- acquired pneumonia in the UK: Report of the Working Party on HospitalAcquired Pneumonia of the British Society for Antimicrobial Chemotherapy Journal of Antimicrobial Chemotherapy 2008;62:5-34

Muzasti Riri Andri, 2011 . Pneumonia Nosokomial. Departemen ilmu penyakit dalam fakultas kedokteran universitas sumatera utara.

Niederman MS. Hospital aquired pneumonia in and on out off the intensive care unit. In : Niederman MS, Sarosi GA, Glassroth J ed. Respiratory Infections 2 nd ed. Philadelphia ; Lippincott Williams \& Wilkins , 2001:197214

PDPI, 2005. Pedoman Diagnosis\& penatalaksanaan pneumonia nosokomial di Indonesia. Indah Offset Citra Grafika; Jakarta.

Peleg Y Anton, Hooper C David. Hospital-acquired infectious due to gram- negative bacteria. $\mathrm{N}$ Engl J Med 2010;362:1804-13

Satyanegara, 2010. Ilmu bedah syaraf. PT Gramedia Pustaka Utama, Jakarta.

Tarsia P, Aliberti S, Cosentini R, Blasi F, 2005. hospitalacquired pneumonia. Institute of Respiratory Diseases University of Milan. IRCCS Fondazione policlinicoManggiagalli-Regina Elena. Milan, Italy

Waterer W. Grant, Wunderink G. Richard, 2003. Severe Infections Caused by Pseudomonas Aeruginosa Perspectives on Critical Care Infectious Diseases, Volume 7, 37-54. Kluer Academic Publisher

WHO/CDS/CSR/EPH/2002. Prevention of Hospital-Acquired Infection, 12

Zubir Zuhrial. Hospital Acquired (Nosocomial) Pneumonia. Naskah Lengkap Pertemuan Ilmiah Tahunan (PIT VII) Departemen Penyakit Dalam FK USU. Medan 24 Maret 2006 
